\title{
Zinc Phosphide and Argel (Gomphocarpus sinaicus Boiss) leaves as a rodenticide on the Norway rat, Rattus norvegicus Comparative Studies under Laboratory and Field Conditions \\ Fatma K. Khidr ; A. A. M. Abo-Hashem and M. M. Mortada \\ Plant Protection research institute, Agric., Res., Center
}

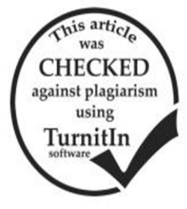

\begin{abstract}
The rodenticidal effect of crude argel (Gomphocarpus sinaicus Boiss) leaves was carried out on Norway rat under laboratory and field circumstances with zinc phosphide in Menofyia Governorate. The laboratory results proved that non-choice also, free - choice feeding tests gave the same trend; a bait $1 \%$ either zinc phosphide and argel ethanolic extract excepted $100 \%$ mortality for Norway rat as well as shorter time to death for zinc phosphide treatment. Argel ethanolic extract bait was more accepted than zinc phosphide with 57.1 and $34.5 \%$, respectively. Also cleared that zinc phosphide more toxic than argel ethanolic leaves extract whereas the acute oral $\mathrm{LD}_{50}$ values were 0.255 and $85.78 \mathrm{mg} / \mathrm{kg}$ b.w respectively, for rattus norvegicus. Oral administration of sub-leathal dose $\left(1 / 4 \mathrm{LD}_{50}\right)$ of each compound induced a noticeable disfunction in (AST), (ALT) enzymes and TP levels as they increased in plasma at 24 and 48 hours after treatment indicating a hepatic damage. Aprolongation of the prothrombin time (PT) had occurred following administration of Argel leaves ethanolic extract indicating disorders in blood coagulation mechanism but no effect on (PT) was observed with zinc phosphide treatment. Under the field conditions, zinc phosphide caused $70.6 \%$ population reduction, While Argel leaves ethanol extract reduced $68.0 \%$ of Norway rat, Rattus norvegicus population, while the water extract gave the lowest value (11.3\%).
\end{abstract}

\section{INTRODUCTION}

Egypt suffered from rodent problems in agricultural area at the beginning of the 1980's. The anticoagulant rodenticides were the major advance in rodent control. The anticoagulant compounds are more effective against rodents when used the surplus baiting. The damage by rodents to wheat and sugarcane crops, reached up to 30 and $50 \%$, respectively. During 1982 in some governorate in Egypt. (EL-Deeb, 1990), while the damage at wheat decreased to $0.58 \%$ during 1994 after rodent control using zinc phosphide and anticoagulant rodenticides (Abd ELGalil, 1997). Zinc phosphide is the most commonly used as acute rodenticide and has a relatively long history of use and it is becoming a standard to compare with newly developed rodenticides (Meehan, 1984).

The strategy of rodent pest management programs are very important in Egypt. Bait shyness to zinc phosphide after one day and observed natural resistance or low sensitive on some species ( R.rattus and A. cahirinus) for certain anticoagulant compounds considered a problems would lead to control failure. Due to looking for new compounds (plant extracts) beside zinc phosphide and anticoagulant compounds add to rodent pest management programs

This study aims to the effect of argel crude leaves extract and comparative with zinc phosphide as rodenticide under laboratory and field conditions.

\section{MATERIALS AND METHODS}

1- Tested compounds :-

-Zinc phosphide:- $\mathrm{Zn}_{3} \mathrm{P}_{2}$ (94) \% was obtained from $\mathrm{KZ}$ pesticides company, Egypt.

- Argel leaves extract:-

Argel plant Gomphocarpus sinaicus Boiss (Fam. Asclepiadaceae) was obtained from a local market in Giza. Leaves of argel were dried and grounded then, they were successive extracted with different solvents varied in their polarity i.e. hexane, ethanol, petroleum ether and water according to procedure of (Freedman et al, 1979). The crude extracts were weighed and kept in a deep freezer until use.

\section{2- Tested Animls}

In fields of EL-remaly village, Quossna district, Menoufia Governorate. The adult of the Norway rat, Rattus norvegicus were trapped. Animals were transported to the laboratory. They were caged individually with standard diet contains $(65 \%$ crushed maize, $25 \%$ ground wheat, 5\% sugar, 5\% corn oil) and water supplied add labium. The unhealthy and pregnant animals were excluded. Animals were weighed and given a reference number for each one.

\section{3- Laboratory Experiments.}

Non choice feeding method:

A group of 10 rats individually caged were used for each treatment. The first group was offered 50 gram of crushed maize containing $1 \%$ zinc phosphide for $24 \mathrm{~h}$ while the second group was offered $1 \%$ argel extracts for 4 successive days. Another group was offered plain crushed maize as check control. The consumed amount of bait was daily calculated. The treated bait was removed and the survivor animals were fed on the standard diet and observed for 28 days. Mortality was recorded during this period.

Free choice feeding method:

The free choice feeding method was used to determine the compound palatability by comparing its consumption with that of standard challenge diet according to palmateer (1974)

Ten rats were caged individually for zinc phosphide or argel extract and one as a control. Each rat was offered $50 \mathrm{~g}$ of crushed maize containing either $1 \%$ one of the mention compound and $50 \mathrm{~g}$ of standard diet in small separate dishes. The position of the two dishes was altered daily to avoid feeding preference for a certain location. The consumed amount of the poisoned bait and standard diet was recorded daily for 4 successive days then the poisoned bait was removed and the survivor animals were fed on the standard diet.

Dead animals were counted daily up to 28 days. And bait acceptance was recorded as follows:-

Acceptance $\%=\quad$ Consumed amount of treated bait Consumed amount of treated bait + standard diet 
Determination $\mathbf{L D}_{\mathbf{5 0}}$ :

Acute oral $\mathrm{LD}_{50}$ of the mention compound were determined. Animals of the Norway rat were fasted for about $12 \mathrm{~h}$. before treatment Serial doses of both compounds were measured as $\mathrm{mg} / \mathrm{kg}$ body weight and mixed with small amount of vegetable oil and orally administrate red to the animals using stomach tubes, and then water and diet were offered 2 hours after treatment. Five animals were used for each dose. A parallel control test was conducted using plain vegetable oil. Mortality percentages and time to death were recorded up to 4 and 10 days post -zinc phosphide and argel treatments, respectively. Dead animals were autopsied to confirm symptoms of poisoning.

\section{Biochemical studies}

Effect of sub lethal dose $\left({ }^{1} / 4 \mathrm{LD}_{50}\right)$ of argel leaves ethanolic extraction and zinc phosphide on some enzymes activity was studied as physiological response.

Animals were orally incubated with $(21.45 \mathrm{mg} / \mathrm{kg}$. b.w.) of argel extracted by ethanol or $(0.064 \mathrm{mg} / \mathrm{kg}$. b.w $)$ of zinc phosphide. Blood samples were collected from each animal by retro- orbital sinus puncture in tri sodium citrate $3.8 \%$ as an anticoagulant and centrifuged at 3000 r.p.m. for 15 minutes. Plasma was collected and frozen until used.

\section{Determination of AST and ALT enzymes:}

The activity of AST and ALT was detected according to the method of Reitman and Frankel (1957) using commercial reagents of Boehring.

\section{Determination of total protein:}

Colorimetric determination of TP in plasma of treated and untreated animals was conducted as a method of Gornall et al. (1968) using commercial reagents of Boehring.

Determination of blood coagulation Index:

Prothrombin time (PT) was determined in plasma of treated and untreated animals according to Dacie and Lewis (1984) using the fibrometer and commercial reagents obtained from Hoechst company.

4- Field experments:-

Field evaluation of crushed maize bait containing either $1 \%$ Zinc phosphide or $1 \%$ different extract of argel was carried out under the field conditions of at EL-remaly village, Quossna district, Menoufia Governorate. An infested area with the Norway rat, Rattus norvegicus was chosen and divided into 5 plots, each of one feddan. One plot was chosen for each compound and one plot was left without treatment as check control. The population density of the rats was estimated pre-and post treatment using food consumption method according to Dubock (1984). Two Kilograms of the candidate bait were packed into plastic sacks each contained $50 \mathrm{~g}$ and distributed in the chosen plot for 5 days.

The consumed amount of each tested bait was recorded. The percentage of population reduction was calculated as follows:-

Population reduction $\%=$ (pre-treatment consumed - Post $\times 100$ Pre-treatment consumed

\section{RESULTS AND DISCUSSION}

Laboratory studies:-

Non-choice feeding methods:-

Our results in Table (1). cleared that non-choice feeding test excepted $100 \%$ mortality with consumption of
2.2 and $10.7 \mathrm{~g} / \mathrm{rat}$, successively, a bait containing either $1 \%$ zinc phosphide or argel leaves extracted by ethanol. Then followed by 70 and $40 \%$ mortality with hexane and petroleum ether extracts with 9.2 and $6.3 \mathrm{~g}$ consumption, successively.

Argel leaves gave the lowest mortality percentage $10 \%$, extracted by water although a considerable amount of bait consumption $7.9 \mathrm{~g}$ were up taken. A considerable variation in the time to death was observed, 13 hours for zinc phosphide and the average time to death was 5.8, 8.6, 10.3 and 13 days for argel extracted by ethanol, hexane, petroleum ether and water, respectively. This mean that ethanol argel extract killed te animals in short time while the opposite was observed with argel extracted by water

Table 1. Effect of bait containing 1\% zinc phoshide for 24 hour or $1 \%$ argel crude extract for 4 days against Norway rat using none choice feeding method.

\begin{tabular}{llcccc}
\hline \multirow{2}{*}{ Compound } & Aver. bait & \multicolumn{2}{c}{$\%$} & \multicolumn{2}{c}{ Time to death } \\
& & consum .(g) & Mort. & Range & Mean \\
\hline Zinc phosphide & 2.2 & 100 & $7-19(\mathrm{~h})$ & $13 \mathrm{~h}$ \\
\hline \multirow{3}{*}{ Ergel } & Ethanol & 10.7 & 100 & $5-9(\mathrm{~d})$ & $5.8 \mathrm{~d}$ \\
leaves & Petroleum ether & 9.2 & 70 & $5-9(\mathrm{~d})$ & $8.6 \mathrm{~d}$ \\
& 6.3 & 40 & $8-20(\mathrm{~d})$ & $10.3 \mathrm{~d}$ \\
& Water & 7.9 & 10 & $0(\mathrm{~d})$ & $13.0 \mathrm{~d}$ \\
\hline
\end{tabular}

Free Choice feeding method:-

The efficacy of $1 \%$ Zinc phosphide and different extracts of argel plant when tested with free choice method was illustrated in Table(2)Data indicate that both zinc phosphide and argel leaves ethanol extract induced complete mortality followed by 60,30 and $20 \%$ for argel extracted with hexane, petroleum ether and water, respectively. Results revealed that it was 17 hours for zinc phosphide, mean of time required to death, and 6.3, 7.7, 9.4 and 15.0 days for argel leaves extracted with ethanol, hexane, petroleum ether and water, consecutively. On the other hand, argel ethanol extract bait was more accepted to albino rat than zinc phoshoide. A wide variation was observed for the palatability of rats to baits which treated with the four extracts. The tested extracts could be arranged according to their acceptance in a descending order as follows: argel leaves extracted by ethanol, > hexane $>$ petroleum ether $>$ water.

Table 2. Effect of bait containing $1 \%$ zinc phoshide for 24 hour or $1 \%$ argel crude extract for 4days against Norway rat using free choice feeding.

\begin{tabular}{|c|c|c|c|c|c|}
\hline \multirow{2}{*}{\multicolumn{2}{|c|}{ Compound }} & \multirow{2}{*}{\multicolumn{2}{|c|}{$\begin{array}{c}\% \\
\% \\
\text { Accept. Mort. }\end{array}$}} & \multicolumn{2}{|c|}{ Time to death } \\
\hline & & & & Range & Mean \\
\hline \multicolumn{2}{|c|}{ Zinc phosphide } & 34.5 & 100 & 6-24 (h) & $17(\mathrm{~h})$ \\
\hline Argel & Ethanol & 57.1 & 100 & $5-9(d)$ & $6.3(\mathrm{~d})$ \\
\hline leaves & Hexane & 47.9 & 60 & $6-15$ (d) & 7.7 (d) \\
\hline extract & Petroleum ether & 28.7 & 30 & $7-18(d)$ & $9.4(d)$ \\
\hline by & Water & 32.8 & 20 & $10-22(d)$ & $15.0(d)$ \\
\hline
\end{tabular}

Acute oral toxicity:.

The $\mathrm{LD}_{50}$ of argel ethanolic leaves extract and zinc phosphide of Norway rat, $R$. norvegicus is shown in Table (3), The $\mathrm{LD}_{50}$ values were 85.78 and $0.255 \mathrm{mg} / \mathrm{kg}$ b.w. for argel and zinc phosphide, respectively. It was cleared that zinc phosphide exhibited high toxicity to Norway rat, $R$. norvegicus than argel ethanolic extract. 
Table 3. AcuteLD $D_{50}$ of argel ethanolic extract and zinc phosphide on Norway rat, $R$. norvegicus.

\begin{tabular}{lcc}
\hline compound & LD $_{\mathbf{5 0}} \mathbf{~ m g} / \mathbf{k g ~ b . w .}$ & Slope \\
\hline Argel leaves extract & 85.78 & 0.829 \\
Zinc phosphide & 0.255 & 0.842 \\
\hline
\end{tabular}

Biochemical Response:-

AST and ALT are important and critical in biological processes. They have role in amino acid metabolism and biosynthesis and they are considered as specific indicators of liver damage.
Data in Table (4), show that administration of $1 / 4$ $\mathrm{LD}_{50}$ of zinc phosphide or ethanolic argel extract resulted in significant rise of transaminases (AST and ALT) activity and total protein indicating a hepatic disorder and /or damage. AST, ALT and total protein level in plasma was significantly elevated to $37.3,24.3$ and $23.1 \%$ than control value when measured at 24 hours 18.3., 10.3 and $7.8 \%$ at 48 hours post-zinc phosphide treatment, respectively.

Table 4. Effect of subleathal dose (1/4 LD $\left.\mathrm{LD}_{50}\right)$ of zinc phoshide and argel ethanolic extract on AST, ALT enzymes, total protein and prothrombin time (P.T) in plasma of Norway rat, R.norvegicus

\begin{tabular}{|c|c|c|c|c|c|c|c|c|}
\hline \multirow{3}{*}{$\begin{array}{l}\text { Tested } \\
\text { Compound }\end{array}$} & \multirow{3}{*}{$\begin{array}{c}\text { Biochemic al } \\
\text { Parameter }\end{array}$} & \multirow{3}{*}{$\begin{array}{c}\text { Control } \\
\text { Mean } \pm \text { S.E }\end{array}$} & \multicolumn{6}{|c|}{ Period after treament } \\
\hline & & & \multicolumn{2}{|l|}{$24 \mathrm{~h}$} & \multicolumn{2}{|c|}{$48 \mathrm{~h}$} & \multicolumn{2}{|l|}{$72 \mathrm{~h}$} \\
\hline & & & Mean \pm S.E & $\%$ diff & Mean \pm S.E & $\%$ diff & Mean \pm S.E & $\%$ diff \\
\hline & AST (U/L) & $18.3 \pm 0.3$ & $25.5 \pm 0.2$ & $* * 37.3$ & $28.3 \pm 0.72$ & $* * 50.8$ & $23.6 \pm 0.46$ & $* * 22.3$ \\
\hline Zinc & ALT (U/L) & $10.3 \pm 1.33$ & $12.8 \pm 1.3$ & $* 24.3$ & $16.3 \pm 0.67$ & $* * 58.3$ & $12.7 \pm 0.43$ & $* 23.3$ \\
\hline \multirow{2}{*}{ phosphide } & Total protein $(\mathrm{g} / \mathrm{dl})$ & $7.8 \pm 0.1$ & $9.6 \pm 0.4$ & $* 23.1$ & $10.8 \pm 0.3$ & $* * 38.5$ & $8.5 \pm 0.7$ & 8.9 \\
\hline & P.T time (second) & $10.4 \pm 1.3$ & $11.3 \pm 1.4$ & 8.7 & $12.2 \pm 1.3$ & 17.3 & $11.0 \pm 1.5$ & 5.8 \\
\hline \multirow{4}{*}{$\begin{array}{l}\text { Argel } \\
\text { ethanolic } \\
\text { extract }\end{array}$} & $\operatorname{AST}(\mathrm{U} / \mathrm{L})$ & $18.3 \pm 0.3$ & $27.3 \pm 0.86$ & $* 49.2$ & $30.2 \pm 0.43$ & $* * 65.0$ & $21.3 \pm 0.25$ & $* * 16.4$ \\
\hline & $\operatorname{ALT}(\mathrm{U} / \mathrm{L})$ & $10.3 \pm 1.33$ & $12.6 \pm 0.23$ & 22.3 & $13.6 \pm 0.42$ & $* * 32.0$ & $12.0 \pm 0.32$ & 16.5 \\
\hline & Total $\operatorname{protein}(\mathrm{g} / \mathrm{dl})$ & $7.8 \pm 0.1$ & $9.41 \pm 0.6$ & $* 20.6$ & $10.9 \pm 0.5$ & $* * 39.7$ & $8.3 \pm 0.4$ & 6.4 \\
\hline & P.T time (second) & $10.4 \pm 1.3$ & $14.3 \pm 1.6$ & $* 37.5$ & $17.1 \pm 2.3$ & $* 64.4$ & $12.4 \pm 1.3$ & 19.2 \\
\hline
\end{tabular}

*Significant $\quad$ ** High significant

Similar results were obtained when these parameters were measured in the plasma of animals treated with argel extract. An elevation of prothrombin time (PT) had occurred by argel extract treatment. The P.T. value was raised from 10.4 seconds for control to reach 14.3 and 17.1 seconds at 24 and 48 hours posttreatment, respectively. However, zinc phosphide treatment had no significant effect on prothrombin time. A noticeable decreasing in all values level of AST, ALT, total protein and prothrombin time was recorded at 72 hours post-treatment of Zinc phosphide and argel extract but it was over than control.

Our results agree with those obtained by Mourad (2007), El-Deeb et al (2011) and Eisa and Yassin (2016).

\section{Field treatments}

Our results showed that zinc phosphide1 \% was the most effective and $70.6 \%$ in reduction rat population followed by argel ethanol extract $4 \%$ gave $68.0 \%$ while argel extracted by hexane and petroleum ether caused 37.7 and $19.0 \%$ in reduction rat population, respectively .The lowest effective was for extract by water as it gave only $11.3 \%$ in population reduction Table (5).

Table 5. Field experiments of zinc phoshide compare with plant extract of argel leaves against the Norway rat, $R$. norvegicus at Menoufia Governorate

\begin{tabular}{|c|c|c|c|c|}
\hline \multirow[b]{2}{*}{ Comp. } & \multicolumn{3}{|c|}{ Bait Consum. (g)/ Feddan } & \multirow[b]{2}{*}{$\stackrel{\%}{\%}$} \\
\hline & $\begin{array}{c}\text { Pre- } \\
\text { treatment }\end{array}$ & Treatment & $\begin{array}{l}\text { Post- } \\
\text { treatment }\end{array}$ & \\
\hline Zinc phosphide & 459 & 650 & 135 & 70.6 \\
\hline Ethanol & 460 & 752 & 147 & 68.0 \\
\hline Hexane & 480 & 730 & 299 & 37.7 \\
\hline leaves Petroleum ether & 630 & 802 & 510 & 19.0 \\
\hline Water & 620 & 880 & 550 & 11.3 \\
\hline
\end{tabular}

Zinc phosphide gave $650 \mathrm{~g} /$ feddan while it was 752, 730 and $802 \mathrm{~g} /$ feddan for argel extracts with ethanol, as average of bait consumption followed by Hexane and petroleum ether while the highest amount was $880 \mathrm{~g}$ in case of extract by water.

The obtained results cleared that ethanolic extract of argel to be promising compound as a rodenticide in control of rates compare with zinc phosphide. This agree with Ibrahim (2001) and Rezk (2006).

\section{REFERENCES}

Abo Hashem,A.A.M (2013). Rodenticidal effect of Argel (Gomphocarpus sinaicus Boiss) leaves on the Norway rat (Albino), Rattus norvegicus , under laboratory conditions. Journal of Applied Sciences Research, 9(3): 1690-1695, 2013

Caughley,J.;M,Bomford;B.Parker;R.Sinclair;J.Griffths AND d.Kelly (1998). Managing vertebrate pests: rodents. Canberra, Bureau of Resource Sciences.

Dacie, J. V. and S. M. Lewis (1984). Practical Hacmatology; (6th Ed.) Churchill Livingstone, Edinburgh, London, Melbourne and New York: 32-94.

Dubock, A.C. (1984). Pulsed baiting-a new technique for high potency, slow acting rodenticides. Proc. Conf. of the organization and practice of vertebrate pest control, U.K., 105-143.

Eisa,Y.A.E. and E.M.A. Yassin (2016). Comparative studies between zinc phosphide and oshar leaves extract as a rodenticide against Norway rat rattus norvegicus (berkenhout) under laboratory and field conditions.J.Plant Prot. And Path, Mansoura Univ.,Vol.7(4):233-236. 
El-Deeb. H. I, Ibrahim. K.I, Fatma. K.Khidr and AboHashem. A.A.M.(2011) Comparative Studies Between Zinc Phosphide and Golden Ahower Crude Seeds Plant extract As a rodenticide under Laboratory and Field Conditions.

Freedman, B., J, Nowak and W.F. Kwolek(1979). Abioassay for plant derived pest control agent using the European comborer. J. Ecom. Entomol., .. 72. 45-54.

Gill, J. E. (1992). A review of the results from laboratory tests of some rodenticides against eight rodent species Proc. 15th Verteb. Pests Conf. Davis, Univ, California, USA;. 182-191.

Gornall, J.G.; G,J. Bardwill and M.M. David (1968). Determination of serum protein by mean of Biuret reaction. J.Biochem. PP.177-322.

Ibrahim, I. K. (2001). Effect of some wild plant extract as rodenticides on certain rodent species Ph.D. Thesis Fac. Agric. Al-Azhar Univ.184p.

Khidr, F.K. (2001). Comparative studies on avicides of some certain birds. Ph.D. Thesis, Fac. Sci., Zagazig University calcifrol and 2.5\% zinc phosphide. Proc. Second Symp. On Rodent Advances in Rodent Control, Kuwait; : 233-239.
Meehan, A.P, (1984). Rats and mice, their biology and control. (1st Ed) Rentokil Limites. Flecounrt East Grainstead, w. Sussex RH. 192 JY: 249-251.

Mourad E. A.M. (2007): Efficiency of certain environmentally safe plant extracts against rodents. Ph.D. Thesis. Fac. Agric. Sci., Ain-Shams Univ.

Palmateer, S.D. (1974). Laboratory testing of albino rats with anticoagulant rodenticides Proc. 6th Vert. Pest Conf., Anaheim. Calif. March 5-7; 63-72

Reitman, S.M. and S. Frankel (1957). A colorimetric method for the determination of serum glutamic oxaloacetic and glrtamic pyruvic transaminase, Am. J. Clinc. Path. 28: 56-63.

Rezk, A.M.(2006). Teratogenic effect and biochemical changes due to some rodenticides on certain rodent species Ph.D. Thesis. Fac. Agric. Al-Azhar Univ. $125 \mathrm{p}$.

Satpathy, J.M. (1983):Plant species reportedly possessing pest control properties An Ew/UH DATA BASE, Hawaii Univ., Pp. 249.

\section{دراسات مقارنة بين مبيد فوسفيد الزنك و مستخلص أوراق الحرجل كمبيد قوارض تحت الظروف المعملية و الحقلية

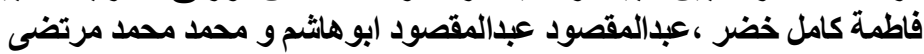 معهـ بحوث وقاية النبات ـ مركز البحوث الزيدراعية}

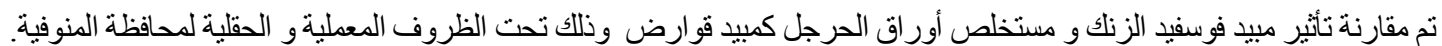

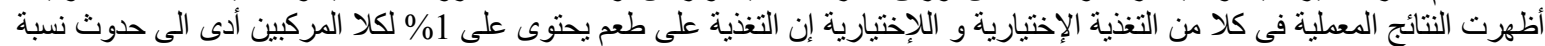

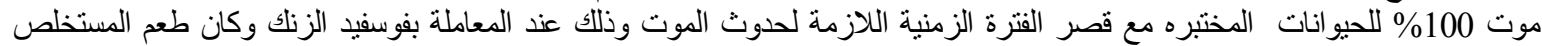

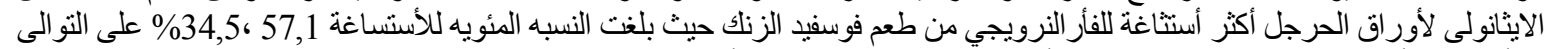

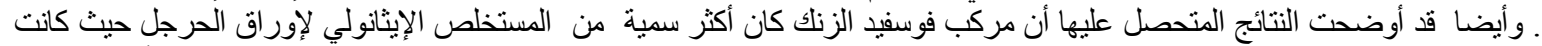

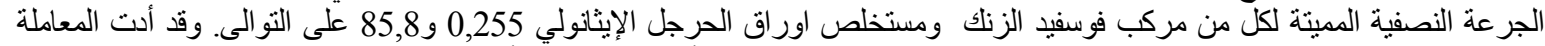

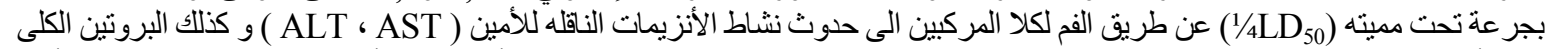

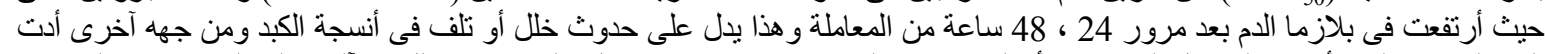

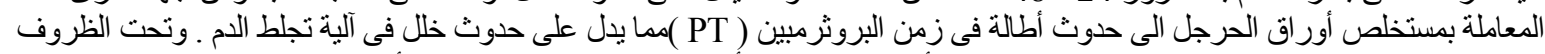

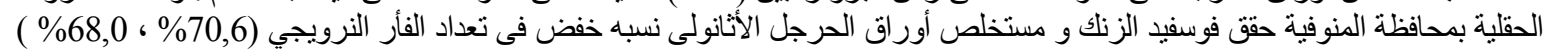
على التو الى فى حين أن مستخلص أوراق الحرجل با لماء أعطى أقل قيمة (11,3\%). 